\title{
Combined effects of diethylpropion and alcohol on locomotor activity of mice: participation of the dopaminergic and opioid systems
}

M.S. Gevaerd ${ }^{1}$,

E.T. Sultowski² and R.N. Takahashi²

\author{
'Departamento de Ciências Biológicas, \\ Universidade do Estado de Santa Catarina and \\ ${ }^{2}$ Departamento de Farmacologia, Centro de Ciências Biológicas, \\ Universidade Federal de Santa Catarina, Florianópolis, SC, Brasil
}

\section{Correspondence \\ R.N. Takahashi \\ Departamento de Farmacologia CCS, UFSC \\ Rua Ferreira Lima, 82 88015-420 Florianópolis, SC Brasil \\ Fax: + 55-48-222-4164 \\ E-mail: takahashi@farmaco.ufsc.br}

Presented at the International Neurobiology Course, Faculdade de O dontologia de Ribeirão Preto, Universidade de São Paulo, Ribeirão Preto, SP, Brasil, May 20-27, 1998.

Research supported by CNPq. E.T. Sultowski was the recipient of a CNPq-PIBIC/UFSC fellowship.

Received December 9, 1998 Accepted September 24, 1999

\section{Abstract}

The widespread consumption of anorectics and combined anorectic + alcohol misuse are problems in Brazil. In order to better understand the interactive effects of ethanol (EtOH) and diethylpropion (DEP) we examined the locomotion-activating effects of these drugs given alone or in combination in mice. We also determined whether this response was affected by dopamine (DA) or opioid receptor antagonists. A total of 160 male Swiss mice weighing approximately $30 \mathrm{~g}$ were divided into groups of 8 animals per group. The animals were treated daily for 7 consecutive days with combined EtOH + DEP $(1.2 \mathrm{~g} / \mathrm{kg}$ and $5.0 \mathrm{mg} /$ $\mathrm{kg}, i p), \mathrm{EtOH}(1.2 \mathrm{~g} / \mathrm{kg}$, ip $), \mathrm{DEP}(5.0 \mathrm{mg} / \mathrm{kg}$, ip $)$ or the control solution coadministered with the DA antagonist haloperidol (HAL, $0.075 \mathrm{mg} /$ $\mathrm{kg}$, ip), the opioid antagonist naloxone (NAL, $1.0 \mathrm{mg} / \mathrm{kg}$, ip), or vehicle. On days 1,7 and 10 after the injections, mice were assessed in activity cages at different times $(15,30,45$ and $60 \mathrm{~min})$ for $5 \mathrm{~min}$. The acute combination of EtOH plus DEP induced a significantly higher increase in locomotor activity (day 1: $369.5 \pm 34.41$ ) when compared to either drug alone (day $1: \mathrm{EtOH}=232.5 \pm 23.79$ and $\mathrm{DEP}=276.0 \pm$ 12.85 ) and to control solution (day 1: $153.12 \pm 7.64$ ). However, the repeated administration of EtOH (day 7: $314.63 \pm 26.79$ and day 10: $257.62 \pm 29.91$ ) or DEP (day 7: $309.5 \pm 31.65$ and day 10: $321.12 \pm$ 39.24) alone or in combination (day 7: $459.75 \pm 41.28$ and day 10: $427.87 \pm 33.0$ ) failed to induce a progressive increase in the locomotor response. These data demonstrate greater locomotion-activating effects of the EtOH + DEP combination, probably involving DA and/or opioid receptor stimulation, since the daily pretreatment with HAL (day 1: $\mathrm{EtOH}+\mathrm{DEP}=395.62 \pm 11.92$ and $\mathrm{EtOH}+\mathrm{DEP}+\mathrm{HAL}=$ $371.5 \pm 6.76$; day $7: \mathrm{EtOH}+\mathrm{DEP}=502.5 \pm 42.27$ and $\mathrm{EtOH}+\mathrm{DEP}$ $+\mathrm{HAL}=281.12 \pm 16.08$; day 10: $\mathrm{EtOH}+\mathrm{DEP}=445.75 \pm 16.64$ and $\mathrm{EtOH}+\mathrm{DEP}+\mathrm{HAL}=376.75 \pm 16.4$ ) and NAL (day 1: EtOH + DEP $=553.62 \pm 38.15$ and $\mathrm{EtOH}+\mathrm{DEP}+\mathrm{NAL}=445.12 \pm 55.67$; day 7 : $\mathrm{EtOH}+\mathrm{DEP}=617.5 \pm 38.89$ and $\mathrm{EtOH}+\mathrm{DEP}+\mathrm{NAL}=418.25 \pm$ 61.18; day 10: $\mathrm{EtOH}+\mathrm{DEP}=541.37 \pm 32.86$ and $\mathrm{EtOH}+\mathrm{DEP}+\mathrm{NAL}$ $=427.12 \pm 51.6$ ) reduced the locomotor response induced by combined administration of EtOH + DEP. These findings also suggest that a major determinant of combined anorectic-alcohol misuse may be the increased stimulating effects produced by the combination.

\section{Key words}

- Diethylpropion

- Ethanol

- Locomotor activity

- Dopamine

- Opioid

- Mice 


\section{Introduction}

In Brazil there is widespread consumption of amphetamine-like anorectic drugs such as diethylpropion (DEP), fenproporex and mazindol, and recent reports have shown that a considerable proportion of this consumption is based on non-proprietary prescriptions $(1,2)$. Among misused anorectics, DEP is a phenylethylamine compound that significantly increases catecholamine levels $(3,4)$. Although DEP was introduced as an efficient anorectic devoid of central stimulant activity, further studies have shown that DEP induces amphetamine-like effects, such as increases in locomotor activity, stereotypies and place preference (5-7). Moreover, similarly to potent psychostimulants, the repeated administration of DEP results in an enhancement of sensitivity, a response frequently referred to as sensitization (6). Sensitization is currently being evaluated as a potential model for drug addiction and for drug-induced psychosis in humans $(8,9)$. Numerous studies indicate that both the activating effects of many drugs of abuse, such as cocaine, amphetamine and ethanol (EtOH), and the expression of sensitization to those effects involve a direct or indirect action on the central dopaminergic (DAergic) neurons (10-15).

Combined anorectic-alcohol misuse is also a prevalent problem in Brazil. Indeed, there are anecdotal reports of extensive consumption of anorectic drugs by truck drivers in order to stay awake and an aggravating factor is that in some cases the anorectic drug is taken with alcohol. The use of this combination may reflect the popular belief that the stimulatory action of DEP is enhanced when the drug is mixed with alcohol. Thus, in a previous study on this kind of interaction, we confirmed the increased locomotion-stimulating effect of combined $\mathrm{EtOH}$ and mazindol, another anorectic, and that this response was not simply induced by an additive effect of the separate action of these drugs (16).

In the light of these considerations, the present experiments were designed to assess the locomotion-activating effects of the DEP + EtOH combination after acute and repeated injection in mice. In addition, because of the known link between DAergic-opioid systems and the locomotion-stimulating effects of psychostimulants and alcohol $(17,18)$, we also determined the involvement of DAergic and opioid receptors in the responses induced by DEP and EtOH by coadministering them with dopamine (DA) and opioid receptor antagonists.

\section{Material and Methods}

\section{Animals}

A total of 160 male Swiss mice weighing approximately $30 \mathrm{~g}$ from our colony were housed in groups, on a 12-h light/dark cycle, at $23 \pm 1{ }^{\circ} \mathrm{C}$. Food and tap water were available ad libitum.

\section{Drugs}

The drugs used were diethylpropion (Medley, Campinas, SP, Brazil), analytical grade ethanol (Merck, São Paulo, SP, Brazil), haloperidol and naloxone (RBI, Natick, MA, USA). DEP and naloxone were dissolved in distilled water. Haloperidol was dissolved in $0.025 \%$ carboxymethylcellulose and diluted with distilled water. Ethanol was diluted in $\mathrm{NaCl}$ to $12.5 \%$ (v/v) concentration. The control solution consisted of an equivalent volume of distilled water plus vehicle. All drugs were administered intraperitoneally ( $i p)$. Injection volumes were 0.1 $\mathrm{ml} / 10 \mathrm{~g}$ body weight for DEP and control solution, and $0.12 \mathrm{ml} / 10 \mathrm{~g}$ body weight for $\mathrm{EtOH}$.

\section{Apparatus and procedures}

The locomotor activity of each animal 
was measured in a wood cage ( $40 \times 12 \times 20$ $\mathrm{cm}$ ) with a steel grid floor and equipped with three parallel horizontal infrared beams positioned $2 \mathrm{~cm}$ above the floor and spaced evenly along the longitudinal axis. The activity cages were linked to a digital counter which recorded photocell beam interruptions. All experiments were conducted between 8:00 and 12:00 a.m. Mice were divided into four groups ( 8 animals per group) receiving once daily ip injections of control solution, $\mathrm{EtOH}(1.2 \mathrm{~g} / \mathrm{kg}), \mathrm{DEP}(5.0 \mathrm{mg} / \mathrm{kg})$ or EtOH $+\operatorname{DEP}(1.2 \mathrm{~g} / \mathrm{kg}$ and $5 \mathrm{mg} / \mathrm{kg})$ for 7 consecutive days. After a 2-day washout, the animals received a challenge dose of the same drug. On days 1, 7 and 10 of treatment, mice from all four groups were tested for activity, with data collected during four 5-min blocks, starting at different times $(15,30,45$ and $60 \mathrm{~min}$ after the injections). Following each 5-min block, mice were removed from the activity cages and housed in a holding cage. Mice were not adapted to the activity cages prior to treatment.

During the pretreatment phase, mice received two daily injections for 7 consecutive days. The first ip injection was haloperidol $(0.075 \mathrm{mg} / \mathrm{kg})$, naloxone $(1.0 \mathrm{mg} / \mathrm{kg})$ or control solution, immediately followed by a second ip injection of EtOH $(1.2 \mathrm{~g} / \mathrm{kg})$, DEP $(5.0 \mathrm{mg} / \mathrm{kg}), \mathrm{EtOH}+$ DEP or control solution. Activity measurements and procedures were the same as those described above for the preceding experiment. The doses of drugs used in the present study were established in our previous report (16) or were chosen from a dosage range reported in the literature.

\section{Statistical analysis}

Two-way ANOVA with repeated measures was used to analyze the influence of drug treatment (between-group factor) and the day of the treatment (within-group factor), as well as the treatment $\mathrm{x}$ day interaction, on locomotor activity. Following sig- nificant ANOVAs, the Newman-Keuls test was used to compare each treatment with the corresponding control value. The accepted level of significance for all tests was $\mathrm{P} \leq 0.05$.

\section{Results}

The effects of acute and repeated administration of control solution, EtOH, DEP and the EtOH + DEP combination on locomotor activity of mice are illustrated in Figure 1. Two-way ANOVA with repeated measures indicated a significant effect only for drug treatment $\left(\mathrm{F}_{(3,28)}=53.5, \mathrm{P} \leq 0.0001\right)$. Subsequent Newman-Keuls tests indicated that EtOH $(1.2 \mathrm{~g} / \mathrm{kg})$ and DEP $(5.0 \mathrm{mg} / \mathrm{kg})$ given alone significantly increased the locomotor activity across 3 testing days compared to the respective control groups. The major finding is that the locomotion-activating effect of combined EtOH + DEP treatment was higher than when each drug was injected alone $(\mathrm{P} \leq 0.05)$. However, as shown by the preliminary ANOVA concerning the day of test factor and the interaction between drug treatment and day factors $\left(\mathrm{F}_{(2,56)}=2.9, \mathrm{P} \geq 0.05\right.$ and $\mathrm{F}_{(6,56)}=0.9, \mathrm{P} \geq 0.05$, respectively), there were no significant differences in activity of treated animals on day 1 compared to subsequent responses to activity cages on days 7 or 10 (Figure 1). Thus, under the conditions and dose schedule used in this study, no sensitization to locomotor response was detected.

Figure 2 shows the effects of haloperidol,

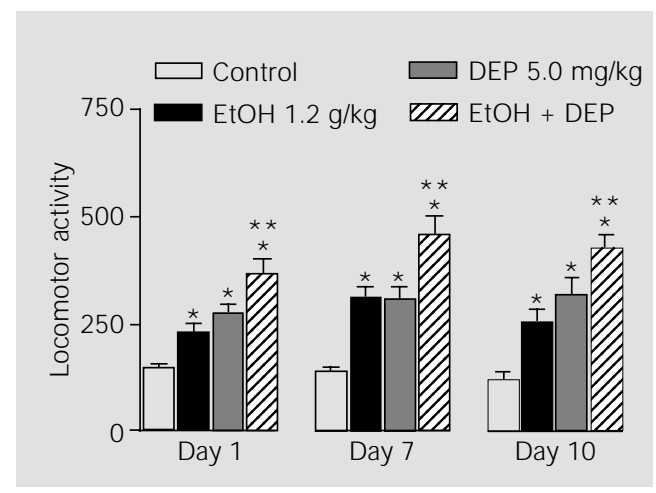

Figure 1 - Effects of control solution (Control), EtOH (1.2 g/kg), DEP $(5.0 \mathrm{mg} / \mathrm{kg})$ or the EtOH + DEP combination on activity counts of mice. The locomotor activity was recorded acutely (day 1 ) and after repeated treatment (day 7 and day 10). Values represent the mean \pm SEM of total activity of 8 mice. ${ }^{*} \mathrm{P} \leq 0.05$ compared to the control group; $* * \mathrm{P} \leq 0.05$ compared to the groups treated with EtOH or DEP alone (Newman-Keuls test). 
Figure 2 - Effects of haloperidol $(0.075 \mathrm{mg} / \mathrm{kg})$ on total activity counts induced by control solution (Control), EtOH $(1.2 \mathrm{~g} / \mathrm{kg}$ ), DEP $(5.0 \mathrm{mg} / \mathrm{kg})$ or the EtOH + DEP combination in mice. The locomotor activity was recorded acutely (day 1 ) and following repeated treatment (day 7 and day 10). Values represent the mean \pm SEM of total activity of 8 mice. $* \mathrm{P} \leq 0.05$ compared to the control group; **P $\leq 0.05$ compared to the groups treated with $\mathrm{EtOH}$ or DEP alone; ${ }^{+} \mathrm{P} \leq 0.05$ compared to the respective control group (Newman-Keuls test).
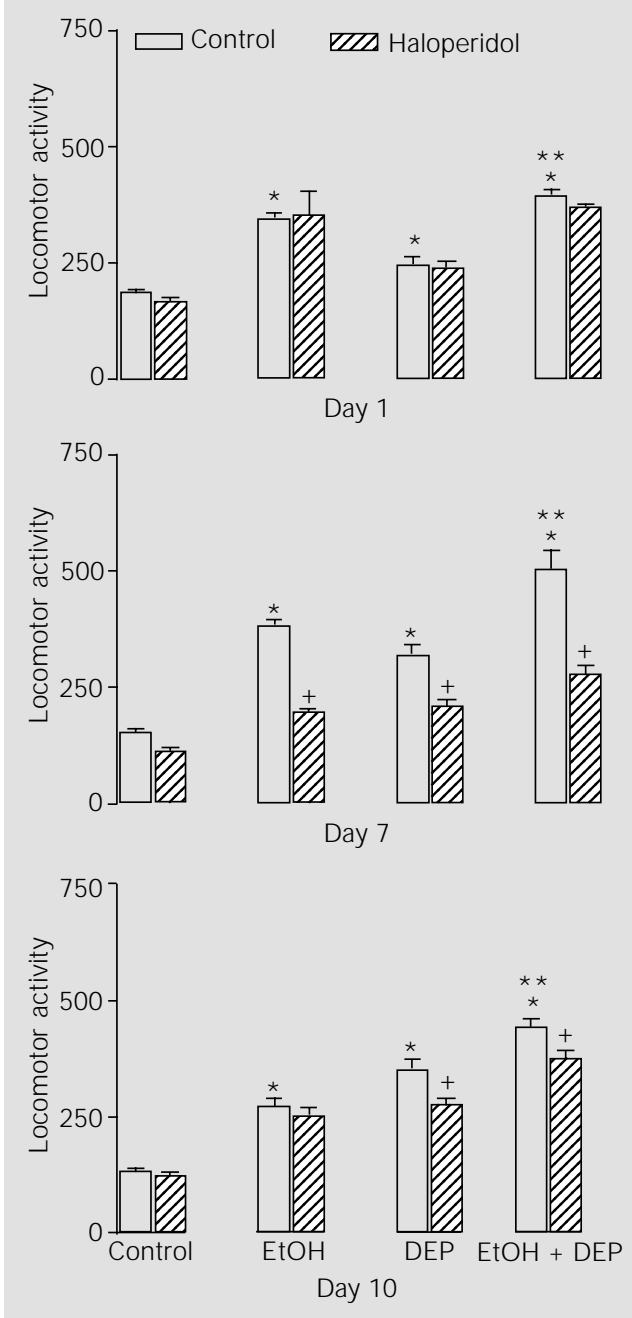

a preferential $\mathrm{D}_{2}$ receptor antagonist, on locomotor activity responses induced by EtOH and/or DEP. Two-way ANOVA with repeated measures indicated significant differences consequent to treatment $\left(\mathrm{F}_{(7,56)}=67.3\right.$, $\mathrm{P} \leq 0.0001)$ and to interaction factor between treatment and day $\left(\mathrm{F}_{(14,112)}=10.1, \mathrm{P} \leq 0.0001\right)$. Further comparisons using the NewmanKeuls test confirmed the increased locomotor activity induced by EtOH and/or DEP on all days of testing. The salient finding is that daily pretreatment with haloperidol $(0.075$ $\mathrm{mg} / \mathrm{kg}$ ) significantly reduced the locomotor effects induced by DEP alone and combined with EtOH on days 7 and 10 (Figure 2).

The effects of pretreatment with naloxone, an opiod antagonist, on the locomotion- stimulating effects of EtOH and/or DEP are presented in Figure 3. Two-way ANOVA with repeated measures demonstrated significant differences only in the treatment factor $\left(\mathrm{F}_{(7.56)}=19.2, \mathrm{P} \leq 0.0001\right)$. Post hoc comparisons using the Newman-Keuls test also confirmed the previous results for experimental animals pretreated with control solution. Interestingly, naloxone significantly reduced only the locomotor response induced by the combined administration of $\mathrm{EtOH}+\mathrm{DEP}$ on days 7 and 10 (Figure 3).

\section{Discussion}

The results of this study suggest that the locomotion-stimulating effect of the combination of EtOH and DEP in mice were greater than the activating effects of either drug alone. These findings confirm and extend literature data on the interaction of EtOH with psychostimulants in animals $(16,19,20)$ and support the popular belief that the stimulatory action of anorectics is enhanced when these drugs are taken with alcohol. In addition, the coadministration of DA or opioid receptor antagonists reduced this increased locomotor response caused by combined drug treatment.

In contrast to some studies reporting sensitized responses following DEP or EtOH administration $(6,21,22)$, the repeated administration of these drugs alone or in combination failed to induce a progressive increase in locomotor activity over days, i.e., sensitization. However, it is important to remember that only one dose of each treatment and one schedule of 7 consecutive days of injections were used.

Although the exact mechanism responsible for the interaction between $\mathrm{EtOH}$ and DEP remains unknown, it is likely that these results are mostly pharmacodynamic in nature. However, a pharmacokinetic interaction cannot be ruled out, since plasma $\mathrm{EtOH}$ or DEP concentrations were not measured.

DAergic systems have been strongly im- 
plicated as mediators of locomotor stimulation in response to many drugs of abuse, including EtOH (10-15). In this study, pretreatment with haloperidol reduced the locomotion-activating effects induced by repeated administration of DEP and EtOH + DEP. Indeed, there are many studies showing that the locomotor stimulation produced by psychostimulants can be reversed by DAergic antagonists, like haloperidol, pimozide, $\mathrm{SCH}-$ 23390 and metoclopramide (23-25). In addition, it is known that the decrease of vesicular DA by reserpine, or the blockage of DA synthesis by $\alpha$-methyl-p-tyrosine, reduces the stimulant effects of psychostimulants, as well as of low doses of EtOH (26-30).

On the other hand, there is anatomical and pharmacological evidence showing a relationship between the DAergic and opioid systems in the locomotor behavior induced by many psychostimulant drugs such as amphetamine (31), cocaine (32) and fencanfamine (25). The results obtained here with the drug combination are in accordance with this notion, since naloxone, administered repeatedly, reduced the increase in locomotor activity induced by EtOH + DEP.

In conclusion, the present results demonstrate that the combination of $\mathrm{EtOH}$ and DEP has a more marked stimulatory activity than either substance alone, which is attenuated by pretreatment with either DA or opioid receptor antagonists. Thus, one might hypothesize that the increased behavioral effects of the EtOH + DEP combination may stem, at least in part, from the enhancement
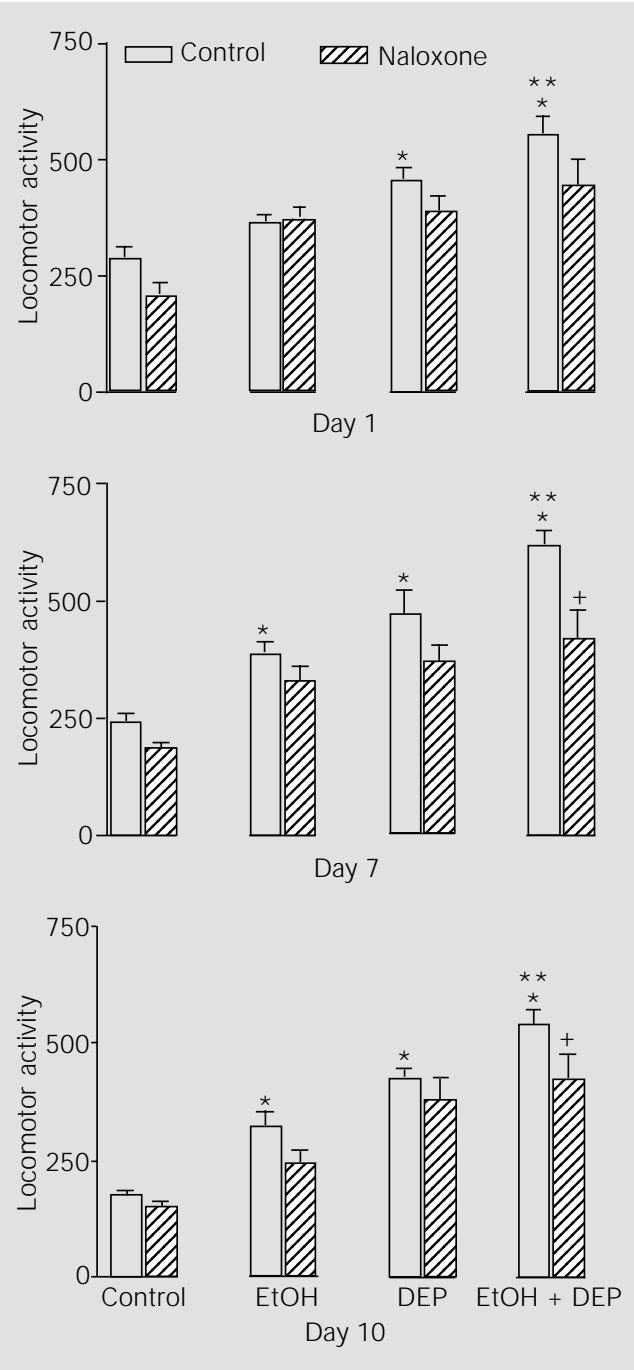

of DAergic and opioid activity in certain brain pathways produced by these drugs. These findings may contribute to the understanding of the frequently reported use of this drug combination by humans.
Figure 3 - Effects of naloxone $(1.0 \mathrm{mg} / \mathrm{kg})$ on total activity counts induced by control solution (Control), EtOH (1.2 g/kg), DEP $(5.0 \mathrm{mg} / \mathrm{kg})$ or the EtOH + DEP combination in mice. The locomotor activity was recorded acutely (day 1) and following repeated treatment (day 7 and day 10). Values represent the mean \pm SEM of total activity of 8 mice. $* \mathrm{P} \leq 0.05$ compared to the control group; $* * \mathrm{P} \leq 0.05$ compared to the groups treated with $\mathrm{EtOH}$ or DEP alone; $+\mathrm{P} \leq 0.05$ compared to the respective control group (Newman-Keuls test).

\section{References}

1. Nappo AS (1996). Consumption of anorexigenic amphetamine-like drugs (diethylpropion, fenproporex and mazindol) and of d,l-fenfluramine in Brazil during the years of 1982 and 1989. Pharmacoepidemiology and Drug Safety, 5: 19-25.

2. Nappo AS, Oliveira EM \& Morosini $S$ (1998). Inappropriate prescribing of antiobesity formulas in Brazil. Pharmacoepidemiology and Drug Safety, 7: 207-212.
3. Hoekenga MT, Dillon RH \& Leyland HM (1978). A comprehensive review of diethylpropion hydrochloride. In: Garattini $\mathrm{S} \&$ Samanin R (Editors), Central Mechanisms of Anorectic Drugs. Raven Press, New York.

4. Silverstone T (1986). Clinical use of appetite suppressants. Drug and Alcohol Dependence, 17: 151-167.

5. Safta L, Cuparencu B, Sirbr A \& Secare- aneanu AL (1976). Experimental observations on the effect of amphepramone on the behavior locomotion, penterazol seizures and electroencephalogram. Psychopharmacology, 50: 165-169.

6. Reimer $A R$, Martin-Iverson MT, Urichuk LJ , Counts RT \& Byme A (1995). Conditioned place preference, conditioned locomotion, and behavioral sensitization occur in rats treated with diethylpropion. 
Pharmacology, Biochemistry and Behavior, 51: 89-96.

7. Planeta CS \& DeLucia R (1998). Involvement of dopamine receptors in diethylpropion-induced conditioning place preference. Brazilian J ournal of Medical and Biological Research, 31: 561-564.

8. Segal DS \& Schuckit M (1983). Animal models of stimulant-induced psychosis. In: Creese I (Editor), Stimulants: Neurochemical, Behavioral and Clinical Perspectives. Raven Press, New York, 131-167.

9. Wise RA \& Leeb K (1993). Psychomotorstimulant sensitization: A unitary phenomenon? Behavioural Pharmacology, 4: 339349.

10. Kalivas PW \& Stewart J (1991). Dopamine transmission in the initiation and expression of drug and stress-induced sensitization of motor activity. Brain Research Reviews, 16: 223-244.

11. Phillips TJ , Dickinson S \& Burkhart-Kasch $S$ (1994). Behavioral sensitization of drug stimulant effects in C57 BL/6J and DBA/ 2] inbred mice. Behavioral Neuroscience, 108: 789-803.

12. Shen EH, Crabbe J C \& Phillips TJ (1995). Dopamine antagonist effects on locomotor activity in naive and ethanol-treated FAST and SLOW selected lines of mice. Psychopharmacology, 118: 28-36.

13. Kuribara $\mathrm{H} \&$ U Uchihashi $Y$ (1994). Effects of dopamine antagonism on methamphetamine sensitization: evaluation by ambulatory activity in mice. Pharmacology, Biochemistry and Behavior, 47: 101-106.

14. Kuribara H (1995). Inhibition of methamphetamine sensitization by post-methamphetamine treatment with SCH 23390 or haloperidol. Psychopharmacology, 119: 34-38.

15. Cohen C, Perrault Gh \& Sanger J (1997). Evidence for the involvement of dopa- mine receptors in ethanol-induced hyperactivity in mice. Neuropharmacology, 36: 1099-1108.

16. Gevaerd MS \& Takahashi RN (1999). Involvement of dopamine receptors on locomotor stimulation elicited by the interaction ethanol and mazindol in mice. Pharmacology, Biochemistry and Behavior, 63: 395-399.

17. Heidbreder C, Goldberg SR \& Shippenberg TS (1993). Inhibition of cocaine-induced sensitization by the $\delta$-opioid receptor antagonist naltrindole. European J ournal of Pharmacology, 243: 123-127.

18. Spanagel R (1995). Modulation of druginduced sensitization processes by endogenous opioid systems. Behavioural Brain Research, 70: 37-49.

19. Masur J, De Souza ML \& Zwicker AP (1986). The excitatory effect of ethanol. Absence in rats, no tolerance and increased sensitivity in mice. Pharmacology, Biochemistry and Behavior, 24: 12251228.

20. Masur J \& Santos HMLM (1988). Response variability of ethanol-induced locomotor activation in mice. Psychopharmacology, 96: 547-550.

21. Phillips TJ, Huson M, Gwiazdon C, Burkhart-Kasch S \& Shen EH (1995). Effects of acute and repeated ethanol exposure on locomotor activity of BXD recombinant inbred mice. Alcoholism, Clinical and Experimental Research, 2: 269-278.

22. Broadbent J, Grahane NJ \& Cunningham CL (1995). Haloperidol prevents ethanolstimulated locomotor activity but fails to block sensitization. Psychopharmacology, 120: 475-482.

23. Schell-Krüger J, Braestrup C, Golembiowska K \& Mogilnicka E (1977). Cocaine: discussion on the role of dopamine in the biochemical mechanisms of action. In:
Ellinwood EH \& Kilbey MM (Editors), Cocaine and Other Stimulants - Advances in Behavioral Biology. Plenum Press, New York, 373-407.

24. Mithani S, Martin-Iverson MT, Phillips AG \& Fibiger HC (1986). The effects of haloperidol on amphetamine- and methylphenidate-induced conditioned place preference and locomotor activity. Psychopharmacology, 90: 247-252.

25. Planeta CS, Aizenstein ML \& DeLucia R (1995). Reinforcing properties of fencanfamine: involvement of dopamine and opioid receptors. Pharmacology, Biochemistry and Behavior, 50: 35-40.

26. Beninger RJ (1983). The role of dopamine in locomotor activity and leaming. Brain Research Reviews, 6: 173-196.

27. Wise RA \& Bozarth MA (1987). A psychomotor stimulant theory of addiction. Psychological Review, 94: 469-492.

28. Stolerman IP \& Shoaib M (1991). The neurobiology of tobacco addiction. Trends in Pharmacological Sciences, 12: 467-473.

29. Di Chiara G \& North RA (1992). Neurobiology of opiate abuse. Trends in Pharmacological Sciences, 13: 185-193.

30. Ahlenius S, Carlson A, Engel J, Svensson T \& Sodersten P (1973). Antagonism by alpha methyl-tyrosine of ethanol-induced stimulation and euphoria in man. Clinical Pharmacology and Therapeutics, 14: 586591.

31. Swedlow NR, Amalric $M \&$ Koob GF (1987). Nucleus accumbens opiate-dopamine interactions and locomotor activation in the rat: evidence for a pre-synaptic locus. Pharmacology, Biochemistry and Behavior, 26: 765-769.

32. Houdi AA, Bardo MT \& Van Loon GR (1989). Opioid mediation of cocaine-induced hyperactivity and reinforcement. Brain Research, 497: 195-198. 